\title{
Analysis of Mediating Effect of Customer Perception in Relation to Service Quality and Customer's Satisfaction in Online Banking Services
}

\author{
Rohit Mahajan ${ }^{a}$, Vinod Kumar ${ }^{b}$, and N. Malati
}

Article History: Received: 11 January 2021; Accepted: 27 February 2021; Published online: 5 April 2021

\begin{abstract}
Qualities of service act as significant in the competition, putting effect upon customer's satisfaction. This research aims for assessing how service quality puts impact customers' satisfaction in the online banking service. E-SERVQUAL with dimensions: efficiency, fulfillment, security, quick responses and easiness to use has been utilized to assess services' qualities of service rendered by bank over internet. The pilot's study was done with 33 responses and cronbach's alpha was 0.882 , which shows that the collected data is valid. A questionnaire comprising of 23 statements was made and 262 responses were analyzed by doing EFA through SPSSv21 and CFA \& Structural Equation Modeling using SPPS AMOS 21.
\end{abstract}

Keywords: Online banking; service quality; E-SERVQUAL; Customer satisfaction

\section{Introduction}

With the passage of time, usage of Internet by businesses has been increased in their marketing practices, because of which companies have increased their online communications with customers. (Farnaz Beheshti Zavareh et al., 2012). Gradually, banking \& finance firms too have begun the delivery of services through online platform. Maximum quantity of banks customers is using online banking services these days. Development in both quantity \& quality of IB/IM research in general is as same as the evolution of MIR in previous fifty years (Boddewyn, Jean J., Iyer, G. R.,1999). As the modern world's marketing is developing, companies delivering services like Banks are being compelled to look for ways for enhancing quality and performance while lowering prices or optimization of operations (Hazlina Abdul Kadir, Reza Masinaei, Nasim Rahmani, 2011). It is common knowledge that "green" values and policies are quite significant for businesses as public awareness of their environmental impacts has grown (Büyüközkan, G., Çifçi, G., 2012). In a developing economy like India, assessing variables influencing consumer understanding, believes, and satisfactions for banking over internet is an important part of overall strategy formulation process of a Bank ( Agarwal, R., Rastogi, S., Mehrotra, A., 2009).

Modern companies can relax their own capacities and manufacture in a more versatile manner to meet a variety of market demands thanks to supply chain management (Hung, S.-J., 2011). It is now more practical for a customer to process all the business transactions \& other transactions through E- banking. Customers can easily pay their bills and can do online purchasing by taking help of the internet banking.

The study's main goal is to look at how services' qualities are related to levels of customers' satisfaction in online banking services. The level of satisfaction with services of a bank over internet is expressed as highly affected by qualities of services in previous studies. In addition, past studies showed a very strong effect of perceived quality of service (customer perception) of online banking services on satisfaction level of customer with regards to services of bank over internet. But no research has expressed service quality's influence on perceptions of customers for services of banks over the internet. On the basis of this, this research's purpose is to analyze service quality's influence on customer's perception towards quality of service of online services provided by bank.

Also no study has shown the customer's perception as a mediation variable in relation to service quality \& customers' satisfaction with reference to online banking services. On its basis, this research's purpose is to analyze the mediation effect of customer's perception in relation to quality of services and levels of customers' satisfaction. The evaluation of quality of electronic banking service may be viewed as a multiple-criteria decisionmaking (MCDM) challenge (Hu, Y., Liao, P., 2011).

\section{Literature Review:}

\section{Online Banking:}

Electronic commerce has a major impact on seller-buyer relationships. Banking has been among highly impacted industries (Methlie, L., Nysveen, H.,1999). Banking customers can now use many platforms to use tools that enable them to perform analyses, make decisions, and conduct financial transactions at home, workplace, or anywhere else (Hoehle, H., Scornavacca, E., Huff, S., 2012). Online Banking is a bank channel by using which customers can use financial and non-financial services on the bank's webpage. Online service of banks was firstly introduced in 1990 and now maximum clients are opting online banking services worldwide. (Mohsen Mazaheri Asad et al., 2016). The selling and purchasing of goods and services over the Internet called E- commerce (Schaupp L., Bélanger F.,2005).

With the advancement of offbeat and secured electronic exchange innovations, more banks are presently utilizing online keeping money both as a value based as well as an enlightening medium. (Alain Yee-Loong 
Chong et al., 2010). Online banking is now one of the most critical aspects of global electronic commerce.

Providing successful electronic service quality (e-SQ) is critical for being and staying competitive in internet banking (Wu Yu-Lung; Chang, M.C.S.; Pei-Chi Yang; Ying-Jun Chen; 2008).

Banks use online services to make internet banking transactions easier and safer for their customers (Md Ariff, MSH., Yun, LO., Zakuan, N., Ismailb, KH., 2013). Online banking gives clients the ability to carry out banking operations at any time and location with low handling costs. (Muslim Amin, 2016). For a growing number of consumers, online services, such as online banking, are becoming an appealing alternative to visiting service outlets or calling call centres. Customers prefer online services (such as online banking services) for a variety of reasons, including ease, feeling more in charge of the service process, avoiding human interaction, and saving time (Kenova V. and Jonasson P.,2006).

\section{Service Quality:}

Qualities of services the most relevant requirements to stay competitive edge and client experience construction. Quality of service may be described as viewpoint of the customer on business entity's dominance in general. It is a shape that is attitude, and outcomes from a comparison of expectations on expectations of success obtained. (Dr. Garima Malik et al., 2017). Website quality is a reliable measure of service quality (Loiacono, E., Watson, R.T., and Goodhue, D.L,2002). Researchers and managers are becoming increasingly interested in measurement of qualities of services in E- banking systems (Jayawardhena, C.,2004).

Online service is a service provided by a website to a client or a prospective user. Online service quality can be described as the spread among services expected by a customer or a user of a given website and the one that webpage has already given. (S. Fatemeh Sakhaei et al., 2014).

It is possible to describe online services as deeds, efforts or performances and these can be distributed via communication technology. As a general user, this may be expressed as evaluations and perspectives on online service distribution excellence in the virtual marketplace too. Online service providers can get competitive benefits by enhancing their efficiency and increasing satisfaction's level of their customers. (Demyana Nathan., 2014).

E-SERVQUAL has been utilized to examine qualities of services of online banking. This study's e-SQ dimensions have been adapted and updated based on E-SERVQUAL elaborated by Parasuraman et al. These dimensions are: Efficiency, Fulfillment, Security, Responsiveness, and Ease of Use (Farnaz Beheshti Zavareh et al., 2012).

\section{Customer Perception:}

Customer perception of online banking services is referred to the electronic theoretical area of consistency. It was designed in a particular way and tested extensively at merchant sites. This is the evaluation of performing standards and efficacy, which facilitates shopping over internet. Customers' Perception can be described as all the assessments and market decisions on the extent of greatness in the automated resources. (Chakib Hamadi, 2010). Managers of companies with web presences must first consider how customers view and assess online customer service in order to provide superior service quality. (Parasuraman, A. Zeithaml, V, Malhotra A,2005).

With the globalization of economies and developing information technology, the issue of supplier selection has become one of the most critical aspects of supply chain management (Dong, G., Yamaguchi, D., Nagai, M., 2006). As organisations compete more on sustainability of supplier chains' capabilities, growing supply has become important (Fu, X., Zhu, Q., Sarkis, J., 2012). Customer perception is the perceived service qualities which can be described as perceptions of usage and perceived ease of use. Perceived usage is an extent to which the person thinks that compared to conventional ways of banking, the online banking is more beneficial. These advantages include enabling them to conduct banking operations whenever and wherever they want. Perceived ease of use, like perceived usefulness, is derived from TAM. Although the customers may assume the application is beneficial, but they may also be helpful at the same time, considering it is difficult to utilize the scheme. (Alain Yee-Loong Chong et al., 2010).

Customer's Perception may be expressed as the perceived efficiency as the standard of operation value derived from post consumption of a service which is focused on consumer interactions. (Dr. Garima Malik et al., 2017). The most critical quality attributes underlying perceived usefulness were accurate services, secured services, speedy transaction, , user engagement, and convenience(Liao, Z., Cheung, M., 2002).

Customers' perceived qualities of services were evaluated across six dimensions: easiness to utilize, which includes user friendliness, transaction speed, search capacity, and easy navigation; content on the Web site, especially information that fits the consumer's needs; accuracy of content; timeliness of response; aesthetics, and privacy.( Zeithaml, V., Parasuraman, A., and Malhorta, A.,2002). As a base to improve execution of services, we need to consider how customers judge efficiencies of services over internet. (Zeithaml,V, 2002).

Service Quality and Customer Perception:

There are several research initiatives aimed at identifying the determinants of consumer behavioural intentions, which include intention of a customer the service provider and spread favourable referrals with the environment, and they mostly concentrate upon cognition factors of customer conduct, viz; services' quality and price perception, with little ability to explain customers' post-buying behaviour (Giovanis, AN., Zondiros, D., 
Tomaras, P., 2014). Fast facilities in banking sector make it easy to use new technology to improve organizational

capabilities and continuity of services to acquire and understand the clients. The use of online banking services offer banks the chance to exercise the passion of customers to believe to have a much awaited profit (Abdullah Bin Omar et al., 2011).

The technology adoption model is a TRA adaptation in the area of informations. TAM claims that an individual's intention to use a system is determined by perceptions of utilities and perceptions of easiness of use, with intention to use acting as a mediator between actual system use and actual system use ( Hanafizadeh, P., Keating, BW., Khedmatgozar, HR., 2014). SPerceived ease of use is often thought to be directly affecting perceived usefulness. Service quality appears as the major variable causing effect online banking operations and it is directly affecting perceptions of customers. (Ahasanul Haque et al., 2009).

A large number of customers have a favorable view of bank's services delivered over internet and their level of satisfaction is higher with bank's services over internet (Dr. Uday Singh Rajput, 2015).

H1: Qualities of services have a direct effect on Customer Perception of online banking services.

\section{Customer's Satisfaction:}

Customer's satisfaction can be described as fulfilling customer's need for goods and services. Customers are satisfied whether the perceived results meet or exceed the service standards of the customers. Customers are not satisfied, if the perceived results do not meet the service standards of the customers. (Muslim Amin, 2016).

A level of satisfaction of a customer is a reflection of the degree of which an enterprise is able to provide satisfaction as per customer's general standards and how well the enterprise is able to match up to an ideal picture. (Dr. Garima Malik et al., 2017). The levels of satisfaction of customers can be assessed as their cognitive ability \& their personal experiences during the relationship's service episodes (Kirakosyan, K., Dănăiaţă, D., 2014).

Understanding the motivations of customers and customer groups for shopping on the websites, as well as monitoring these improvements over time, can help banks to prepare and introduce features and benefits that will improve customer's level of satisfaction. (Wolfinbarger, Mary F., and Gilly, Mary C.,2003). Cross Cultures have a strong impact on customer's response in the market (Farley, John U., \& Lehmann, R., 1994).

\section{Customer Perception and Customer Satisfaction:}

Customer Perception can be evaluated through pre-purchase behavioral aspects of a customer and level of satisfaction can be evaluated through post purchase customer behavior (Khalifa, M., and Shen, N. ,2005). Customer perception of service quality of online banking services is putting a strong effect on the customer's level of satisfaction for bank's services over internet. (Chakib Hamadi, 2010).

When overall perceived quality of online banking services is good, there will be high level of customer's satisfaction with the online services of the bank. (Muslim Amin, 2016). This research adapts the SERVQUAL (Zeithaml et al., 2000, 2002) dimensions in order to investigate customers' perceptions of qualities of services of banking over internet, and their effects on customer satisfaction and potential consumption intentions ( Noel Y. M. Siu, Jeremy C. W.,2005).

The customer perception of different dimensions of service quality viz; efficiency, security, responsiveness, and ease of Use has a positive effect on the level of saisfaction the customer towards online banking services. (Manilall Dhurup et al., 2014).

H2: Customer Perception has a direct effect on Customer Satisfaction in online banking.

\section{Service Quality and Customer Satisfaction:}

When users browse web page of bank, the navigability makes them feel at ease and safe, which increases the likelihood of a transaction being completed (Hernández, B., Jiménez, J., Martín, M. J., 2009). Good quality of online banking services leads to the high level of customer satisfaction with the bank's services provided over internet. (Muslim Amin, 2016).

Customers are highly satisfied with the online banking services due to their reliability (S. Fatemeh Sakhaei et al., 2014).

When overall quality of online banking services is higher, customer's level of satisfaction is higher with the online banking services provided by their banks. (Demyana Nathan., 2014).

H3: Qualities of services have a direct effect on satisfaction level of customer.

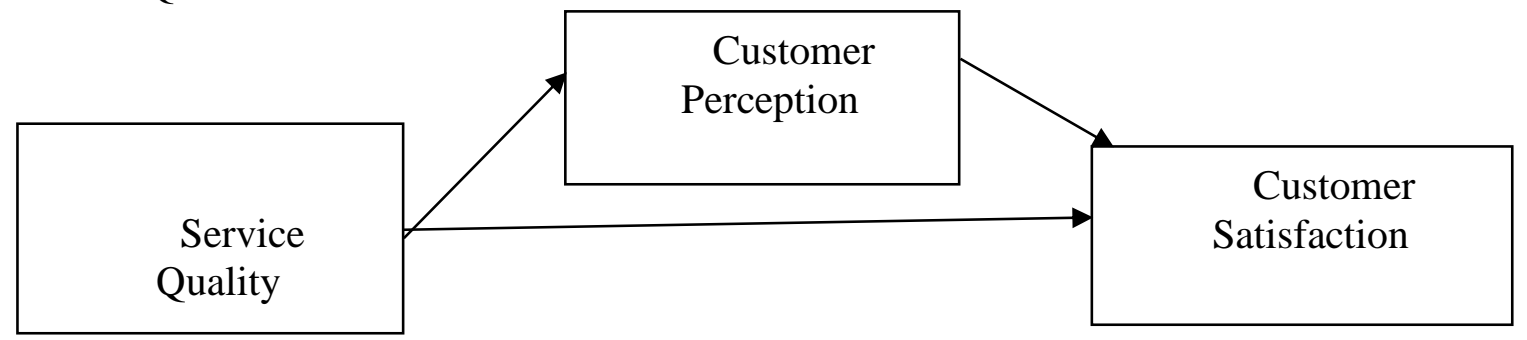

FIGURE 1: THEORETCAL FRAMEWORK 
Reliability and Validity Analysis

Exploratory Factor Analysis

The reliability of the items was evaluated though Coefficient Alpha Test (Cronbach's alpha). The result of the measure was shown in table-2 (above 0.70 is acceptable), which is quite good. Further sample adequacy test was done through Kaiser Meyer-Olkin (KMO statistic. The results are given in the table-1.

KMO and Bartlett's Test

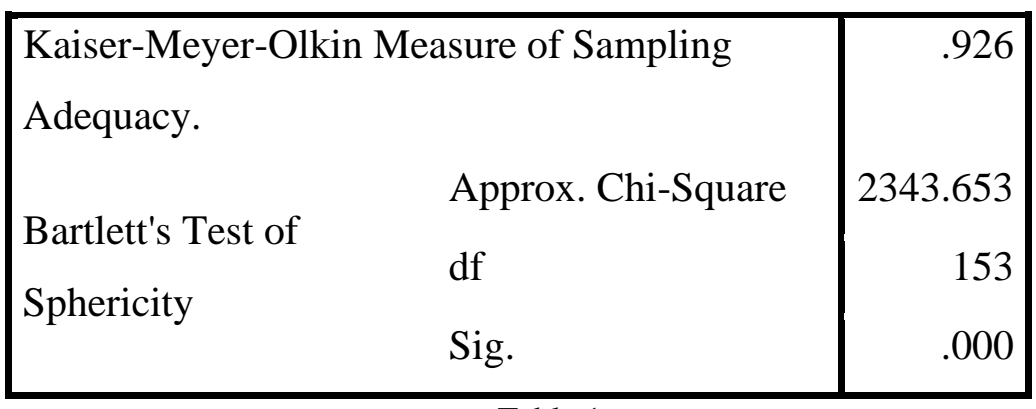

Table 1

Confirmatory Factor Analysis

The validity test was performed by running CFA in AMOS v21. CFA was run with all the three constructs: Service Quality(SQ), Customer Perception(CP) and Customer Satisfaction(CS).

Convergent Validity:

Dataset has been shown convergent as measures of CR as well as AVE are exceeding limit of acceptability. CR's measure is from 0.732 to 0.905 , which is more than range of acceptability of 0.7 , as given in Table $2 \&$ AVE higher than the range of acceptability of 0.5 and its range is between $0.603 \& 0.694$.

\section{Discriminant Validity:}

Measures taken diagonally (Square roots of mean variances explained) must be higher than measures not taken diagonally (correlations among construct). Table 2 expresses higher measure of AVE than Max shared variances (MSV's) of latent variable and higher measures taken diagonally as compared to measures not taken diagonally and therefore expresses that the construct is discriminately valid.

DISCRIMINANT ANALYSIS

\begin{tabular}{|c|c|c|c|c|c|c||}
\hline & CR & AVE & MSV & SQ & CP & CS \\
\hline SQ & 0.905 & 0.694 & 0.506 & $\mathbf{0 . 7 0 3}$ & & \\
\hline CP & 0.875 & 0.639 & 0.392 & $0.624 * * *$ & $\mathbf{0 . 7 9 9}$ & \\
\hline $\mathbf{C S}$ & 0.732 & 0.603 & 0.406 & $0.640 * * *$ & $0.626 * * *$ & $\mathbf{0 . 7 5 0}$ \\
\hline
\end{tabular}

\section{OVERALL FIT OF MODEL}

Model fit indices for measurement and structural model has been done. In the measurement model, key statistics shows that all the latent factor modeled simultaneously, with $\operatorname{CMIN}\left(\sum 2\right)=257.056$, Degrees of freedom $(\mathrm{df})=132, \mathrm{CMIN} / \mathrm{df}\left(\left(\sum 2 / \mathrm{df}\right)=1.947, \mathrm{p}<0.05\right.$, goodness of fit indices (GFI, AGFI, NFI, IFI, CFI) and badness of fit measurement indices (RMR, RMESA, ECVI). The result of the structural model shows GFI=0.901, AGFI=0.872, CFI=0.945, RMR=0.045, RMSEA=0.060.

\section{PATH'S COEFFICIENTS WITH REGARD TO FRAMEWORK}

Evaluation of framework was done through AMOS v21. As per the measures, all the hypotheses are significant measurement of $\mathrm{p}$ less than 0.01 (except $\mathrm{H} 2$, as its $\mathrm{p}$ value is 0.049 , which is less than $\mathrm{p}$ value of 0.05 . The details of all the hypotheses are given in the following table showing relations among the variables.

Table 3 HYPOTHESE TESTING RESULTS

\begin{tabular}{|c|c|c|c|c|c|}
\hline $\begin{array}{c}\text { Hypotheses } \\
\text { Relationship }\end{array}$ & $\begin{array}{c}\text { Path } \\
\text { Estimate }\end{array}$ & SE & CR & P & Result \\
\hline $\begin{array}{l}\text { H1: }<-- \text { SQ } \\
\text { CP }\end{array}$ & 0.440 & 0.052 & 8.412 & $* * *$ & Supported \\
\hline
\end{tabular}




\begin{tabular}{|c|c|c|c|c|c|}
\hline $\begin{array}{l}\mathrm{H} 2: \\
\mathrm{CS}\end{array}$ & 0.128 & 0.065 & 1.967 & $* *$ & Supported \\
\hline $\begin{array}{l}\mathrm{H} 3: \\
\mathrm{CS}\end{array}<--\mathrm{SQ}$ & 0.397 & 0.057 & 6.928 & $* * *$ & Supported \\
\hline
\end{tabular}

Notes: $* \mathrm{p}<0.10 ; * * \mathrm{p}<0.05 ; * * * \mathrm{p}<0.001$

Source: Author's calculation

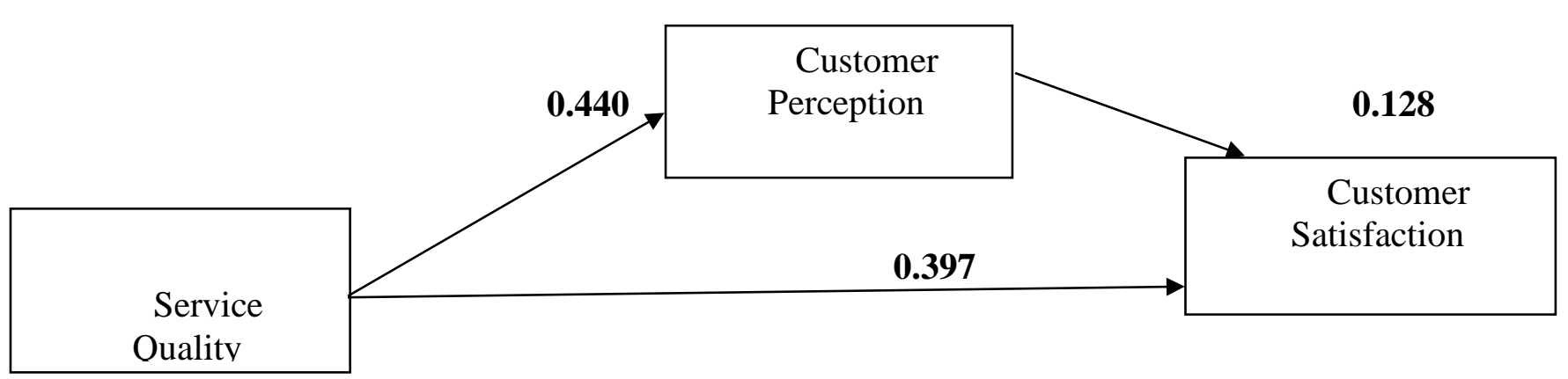

FIGURE 2: RESULT

MEDIATION EFFECT:

The bootstrapped technique (Mooney et al., 1993) in AMOS v21 has been followed to assess the mediation effect. Table 4 represents the estimates for Direct and Indirect effect at $95 \%$ bias-corrected bootstrapped Cis. In the Model, Customer Perception (CP) is partially mediating path ofService Quality (SQ) and Customer Satisfaction (CS) with Direct Effect measure of $0.351(\mathrm{p}=0.001)$ and indirect effect of $0.304(\mathrm{p}=0.001)$.

Mediation Table 4

\begin{tabular}{|l|l|l|l|}
\hline RELATIONSHIP & DIRECT EFFECT & INDIRECT EFFECT & RESULT \\
\hline SQ $\rightarrow$ CP $\rightarrow$ CS & $0.351^{* * *}$ & $0.304^{* * *}$ & Partial Mediation \\
\hline
\end{tabular}

Note: $* * *=\mathbf{p}<0.01, * *=\mathbf{p}<0.05, *=$ "not significant"

\section{Conclusion:}

The study was done to assess the mediating effect of customer perception in relation to qualities of services and satisfaction level of customer. EFA was done using SPSS 21 to explore the factors and three factors namely Service Quality (SQ), Customer Perception (CP) and Customer Satisfaction (CS) were extracted. Confirmatory Factor Analysis was done using SPSS AMOS 21 to test the validity of the theoretical model. Structural Equation Modeling was also done using SPSS AMOS 21 for assessing whether proposed theoretical model is valid or not. The measurements prove the strong relationship between qualities of services \& customer' perceptions and direct relationship between customer's perceptions and satisfaction level of customer . Customer perception has also strong positive impact on customer satisfaction towards online banking services. The results of model fit indices prove the fitness of the model proposed for research. The result of mediation effect shows that there is a partial mediation of Customer's perception in relation to qualities of services and satisfaction level of customer.

Future Scope of Study:

This study can be further elaborated to do mediation analysis of customer perception, customer adoption and customer satisfaction in relation to services' quality and customer's loyalty.

\section{References:}

1. Abdullah Bin Omar et al. (2011). Customer Perception towards Online Banking Services: Empirical Evidence from Pakistan. Journal of Internet Banking and Commerce,16(2), 1-24.

2. Agarwal, R., Rastogi, S., Mehrotra, A., 2009. Customers' perspectives regarding e-banking in an emerging economy. Journal of Retailing and Consumer Services 16, 340-351.

3. Ahasanul Haque et al. (2009). Issues of E-Banking Transaction: An Empirical Investigation on Malaysian Customers Perception. Journal of Applied Science, 9(10), 1870-1879.

4. Alain Yee-Loong Chong et al. (2010). Online banking adoption: an empirical analysis. International Journal of Bank Marketing, 28(4), 261-287.

5. and e-customer loyalty. International Journal of Bank Marketing, 34(3), 280-306.

6. Banking System Based on Cause and Effect Relationships. Procedia Economics and Finance, 36, $210-219$. 
7. Boddewyn, Jean J., Iyer, G. R. (1999). International business research: Beyond Deja Vu? Management International Review, 39(2), 161-184.

8. Büyüközkan, G., Çifçi, G., 2012. A novel hybrid MCDM approach based on fuzzy DEMATEL, fuzzy ANP and fuzzy TOPSIS to evaluate green suppliers. Expert Systems with Applications 39, 3000-3011.

9. Chakib Hamadi. (2010). The Impact of Quality of Online Banking on Customer Commitment. Communications of the IBIMA, 2010, 1-8.

10. Demyana Nathan. (2014). The Relationship Among E-service Quality Dimensions, Overall Internet Banking Service Quality, and Customer Satisfaction in the USA. Journal of Modern Accounting and Auditing, 10(4), 479-493.

11. Dong, G., Yamaguchi, D., Nagai, M., 2006. A grey-based decision making approach to the supplier selection problem. Mathematical and Computer Modeling 46, 573-58

12. Dr. Garima Malik et al. (2017). Analyzing the impact of elevated service quality in online banking services on customer satisfaction. aWEshkar, 22(1), 107-120.

13. Dr. Uday Singh Rajput. ( 2015). Customer Perception on E-Banking Service. Pacific Business Review International, 8(4), 85-94.

14. Farley, John U., \& Lehmann, R. (1994). Cross-national laws and differences in market response. Management Science, 40(1), 111-122.

15. Farnaz Beheshti Zavareh, Mohd Shoki Md Ariff et al. (2012). E-Service Quality Dimensions and Their Effects on E Customer Satisfaction in Internet Banking Services. Procedia - Social and Behavioral Sciences, 40, 441-445.

16. Fu, X., Zhu, Q., Sarkis, J., 2012. Evaluating green supplier development programs at a telecommunications systems provider. International Journal of Production Economics 140, 357-367.

17. Giovanis, AN., Zondiros, D., Tomaras, P., 2014. The antecedents of customer loyalty for broadband services: The role of service quality, emotional satisfaction and corporate image. Procedia - Social and Behavioral Sciences 148, 236 - 244.

18. Hanafizadeh, P., Keating, BW., Khedmatgozar, HR., 2014. A systematic review of Internet banking adoption. Telematics and Informatics 3, 492- 510.

19. Hazlina Abdul Kadir, Reza Masinaei, Nasim Rahmani (2011), Long-Term Effects of Bank Consolidation Program in a Developing Economy, Journal of Asia Pacific Business Innovation and Technology Management .Volume 1, No. 1, P20-30

20. Hernández, B., Jiménez, J., Martín, M. J., 2009. Key website factors in e-business strategy. International Journal of Information Management. 29, 362-371.

21. Hoehle, H., Scornavacca, E., Huff, S., 2012. Three decades of research on consumer adoption and utilization of electronic banking channels: A literature analysis. Decision Support Systems 54, 122 132.

22. $\mathrm{Hu}, \mathrm{Y}$., Liao, P., 2011. Finding critical criteria of evaluating electronic service quality of Internet banking using fuzzy multiple-criteria decision making. Applied Soft Computing 11, 3764-3770.

23. Hung, S.-J., 2011. Activity-based divergent supply chain planning for competitive advantage in the risky global environment: A DEMATELANP fuzzy goal programming approach. Expert Systems with Applications 38, 9053-9062.

24. Jayawardhena, C. (2004). Measurement of service quality in internet banking: the development of an instrument, Journal of Marketing Management, 20(4), 185-207.

25. Kenova V. and Jonasson P. (2006). Quality Online Banking Services, Technical Report, Jonkoping International Business School.

26. Khalifa, M., and Shen, N. (2005). Effects of Electronic Customer Relationship Management on Customer Satisfaction: A Temporal Model. Proceeding of the 38th Annual Hawaii International Conference on System Sciences (HICSS'05), January 3-6, p. 171.

27. Kirakosyan, K., Dănăiaţă, D., 2014. Communication management in electronic banking. Better communication for better relationship. Procedia - Social and Behavioral Sciences 124, 361 - 370.

28. Liao, Z., Cheung, M., 2002. Internet-based e-banking and consumer attitudes: an empirical study. Information \& Management 39, 283-295

29. Loiacono, E., Watson, R.T., and Goodhue, D.L (2002). WEBQUAL: a Measure of Website Quality. In AMA Winter Conference, Austin, TX.

30. Manilall Dhurup et al. ( 2014). Customer Perceptions of Online Banking Service Quality. Mediterranean Journal of Social Sciences,5(2), 2039-2117. 
31. Md Ariff, MSH., Yun, LO., Zakuan, N., Ismailb, KH., 2013. The Impacts of Service Quality and Customer Satisfaction on Customer Loyalty in Internet Banking. Procedia - Social and Behavioral Sciences $81469-473$.

32. Methlie, L., Nysveen, H.(1999). Loyalty of On-line Bank Customers. Journal of Information Technology, 14(4), 375-386.

33. Mohsen Mazaheri Asad et al. (2016). Prioritizing Factors Affecting Customer Satisfaction in the Internet

34. Muslim Amin (2016). Internet banking service quality and its implication on e-customer satisfaction

35. Noel Y. M. Siu, Jeremy C. W. (2005). Measuring Service Quality in Internet Banking; The Case of Hong Kong Journal of International Consumer Marketing, 17(4), 99-116

36. Parasuraman, A. Zeithaml, V, Malhotra A,(2005). E-S-QUAL, A Multiple-Item Scale for Assessing Electronic Service Quality; Journal of Service Research,7(3), 213-233

37. S. Fatemeh Sakhaei et al. (2014). The Impact of Service Quality on Customer Satisfaction in Internet Banking. Journal of mathematics and computer science, 9, 33-40.

38. Schaupp L., Bélanger F. (2005). A Conjoint Analysis of Online Consumer Satisfaction, Journal of Electronic Comerce Research, 6(2), 95-111.

39. Wolfinbarger, Mary F., and Gilly, Mary C. (2003). Shopping Online for Freedom, Control and Fun. California Management Review, 43(2), 34-55

40. Wu Yu-Lung; Chang, M.C.S.; Pei-Chi Yang; Ying-Jun Chen; (2008). The Use of E-SQ to establish the internet bank service quality table IEEE International Conference on Industrial Engineering and Engineering Management, Dec. 2008, 1446-1450.

41. Zeithaml, V., Parasuraman, A., and Malhorta, A. (2002). Service Quality Deliver through Web Sites: A Critical Review of Extant Knowledge.Journal of the Academy of Marketing Sc,30(4),362-375.

42. Zeithaml,V (2002).Service Excellence in Electronic Channels.Managing Service Quality, 12(13) 135 138. 